\title{
The role of diarrhoeagenic Escherichia coli in acute diarrhoeal diseases in Bandar-Abbas, Iran
}

\author{
M. KATOULI, A. JAAFARI and G. R. KETABI
}

\section{Department of Microbiology, Pasteur Institute of Iran, Pasteur Avenue, Tehran, Iran}

\begin{abstract}
Summary. The prevalence of different types of diarrhoea-producing Escherichia coli was measured in 273 patients attending 12 out-patient clinics in Bandar-Abbas, State of Hormozgan, Iran, during March 1984. Enteropathogenic E. coli (EPEC) belonging to 12 different serogroups, of which $\mathrm{O} 128$ and 0126 were the most common, were found in almost $31 \%$ of the patients. Enterotoxigenic strains of $E$. coli (ETEC) were the next most frequent group $(21.9 \%)$; among these, $36(60 \%)$ strains produced heatstable enterotoxin (ST), $14(23.3 \%)$ strains produced both heat-labile enterotoxin (LT) and ST, and $10(16.7 \%)$ strains produced LT only. The same pattern of toxigenicity was observed among the EPEC isolates. Ten of the 12 serogroups encountered in this study contained toxin producers, amongst which strains producing ST were dominant. Enteroinvasive $E$. coli (EIEC) strains were not isolated. These findings suggest that enterotoxin-producing $E$. coli may be an important cause of diarrhoea in this part of Iran.
\end{abstract}

\section{Introduction}

Enterotoxigenic Escherichia coli (ETEC) have been reported to be a major cause of diarrhoea in man throughout the world (Sack, 1975; Rowe et al., 1977), notably in developing countries (Merson et al., 1980). They have also been found to be the commonest cause of travellers' diarrhoea in all countries where surveys have been conducted (Merson et al., 1976; Echeverria et al., 1981; Ryder et al., 1981). The species causes diarrhoea by producing a heat-labile enterotoxin (LT) or a heatstable enterotoxin (ST) or both. The ability to produce enterotoxin is usually plasmid mediated and easily lost from some strains, especially on subculture, probably due to loss of these plasmids (Evans et al., 1977). Available studies suggest geographical differences in the types of enterotoxin produced by these organisms. For example, reports from India, in which cholera-like disease is endemic, consistently imply that strains producing LT are dominant (Ganguly et al., 1980; Sen et al., 1984), whereas in Bangladesh strains producing both LT and ST are most common (Sack et al., 1977; Merson et al., 1979). Nonetheless, it seems that all three enterotoxin types are found in all geographical areas.

The single report of the isolation of ETEC as a cause of infantile diarrhoea in Iran (Mohadjer $e t$

Received 16 April 1987; revised version accepted 16 Feb. 1988. al., 1982), indicates the presence of LT and ST-, and ST-producing strains, in Tehran. In view of the scarcity of data on ETEC as a cause of diarrhoea in Iran, this study was undertaken to establish the role of these pathogens in endemic diarrhoea in different parts of the country and describes, in part, the results of an investigation into the association of different types of enterotoxigenic $E$. coli with diarrhoea in Bandar-Abbas, State of Hormozgan, Iran.

\section{Materials and methods}

\section{Collection of specimens}

Faecal specimens were collected from 273 patients with diarrhoea attending 12 out-patient clinics in BandarAbbas, Hormozgan, during March 1984. Diarrhoea was defined as the passage of six or more unformed stools or four or more unformed stools with blood, per day. None of the patients had taken antibiotics in the preceding week. The specimens were collected on cotton swabs with charcoal and placed in modified Stuart's medium in screw-capped tubes (Gastrin et al., 1968). These were stored and transported in an ice-box to the Pasteur Institute of Iran, Tehran, for microbiological examination.

\section{Cultivation and isolation}

Within one month of collection, the faecal specimens were cultured on the following media: MacConkey Agar 
(Difco); Salmonella and Shigella Agar (Difco), and Thiosulfate-Citrate-Bile salts-Sucrose (TCBS) Agar (Difco). They were inoculated also into Selenite- $F$ broth (BBL) and alkaline peptone water (Difco) and subcultured on to the solid media listed above after incubation at $37^{\circ} \mathrm{C}$ overnight. At least five lactose-fermenting colonies with the appearance of $E$. coli and two colonies of other potential pathogens were identified by the methods of Edwards and Ewing (1972). Identification of EPEC was by slide agglutination with polyvalent and monovalent OK antisera (Difco), and was confirmed by tube agglutination.

\section{Testing for ETEC strains}

A loopful of bacterial growth from nutrient agar slants was inoculated into $250 \mathrm{ml}$ Erlenmeyer flasks containing $10 \mathrm{ml}$ of Trypticase Soy Broth (Difco) supplemented with yeast extract $0.6 \%$. The flasks were incubated at $37^{\circ} \mathrm{C}$ overnight on a shaker at $200 \mathrm{rpm}$. The cultures were centrifuged at $4000 \mathrm{rpm}$ for $20 \mathrm{~min}$ at $4^{\circ} \mathrm{C}$ and supernates assayed for heat-labile toxin (LT) in adult rabbit ileal loops (De and Chatterjee, 1953). As a positive control, a culture filtrate of $E$. coli strain H-10407 (provided by Dr Orskov) containing a non-self-transmissible plasmid coding for LT and ST, was prepared and tested in the same way. Normal saline served as a negative control. A ratio of volume to length $(\mathrm{ml} / \mathrm{cm}) \geq 1$ was taken to indicate the presence of LT. Samples of the same culture supernates were also tested for the presence of heat-stable toxin (ST) in 1-4-day-old suckling mice (Dean et al., 1972). A mean ratio of intestinal weight to remaining carcass weight $>0.083$ was taken to indicate the presence of ST.

Enteropathogenic E. coli (EPEC) were also tested for toxin production. They were grown on trypticase soy agar slants containing yeast extract $0.6 \%$ and lincomycin $90 \mu \mathrm{g} / \mathrm{ml}$ and incubated at $37^{\circ} \mathrm{C}$ overnight. Cultures were then washed with $3 \mathrm{ml}$ of normal saline containing polymixin B 10000 units $/ \mathrm{ml}$ and shaken at $100 \mathrm{rpm}$ for $30 \mathrm{~min}$ at $37^{\circ} \mathrm{C}$. These were centrifuged at $4000 \mathrm{rpm}$ for 15-20 min and supernates were assayed for the presence of LT in the adult rabbit ileal loop and by an agglutinationinhibition method with VET-RPLA Kits (Denka Seiken Co., Japan). These strains were also grown in Erlenmeyer flasks containing trypticase soy broth with yeast extract and tested for ST production as described above.

\section{Testing for EIEC strains}

All lactose-fermenting and 28 lactose non-fermenting isolates of $E$. coli were tested for their ability to cause keratoconjunctivitis in the guinea-pig eye (Sereny, 1955).

\section{Results}

ETEC were detected in the faeces of 60 patients $(21.9 \%)$, aged 3 months to 48 years. In contrast, EPEC were isolated from the faeces of 84 patients
$(30.7 \%)<3$ years old. Salmonellae were isolated from 14 patients $(5 \cdot 1 \%)$ and shigellae from $4(1 \cdot 5 \%)$. EIEC, Vibrio cholerae and $V$. parahaemolyticus were not isolated during the course of this study. Of the 60 ETEC isolates, $36(60 \%)$ produced ST, $10(16.6 \%)$ produced LT and $14(23.3 \%)$ produced both LT and ST (table I). Ten patients $(3.6 \%)$ with mixed infections were encountered: ETEC and a salmonella in 4, and one patient had ETEC and a shigella. The same pattern of mixed infection was also seen with the EPEC strains.

The 84 EPEC strains isolated belonged to 12 different serogroups, of which 0128: K67 (22.6\%) and $0126: K 71(21.4 \%)$ comprised $44 \%$ of the isolates. Seventy-seven of 84 EPEC strains, belonging to 10 of the 12 serogroups, were tested for toxin production; $26(33.7 \%)$ produced ST or LT or both (table II). Strains producing ST were the most

Table I. Distribution of EPEC and ETEC in relation to age among 273 patients

\begin{tabular}{ccrrrr}
\hline & & \multicolumn{3}{c}{ Number of $E$. coli isolated } \\
\cline { 3 - 6 } & & & \multicolumn{4}{c}{ ETEC } \\
\cline { 3 - 6 } $\begin{array}{c}\text { Age group } \\
\text { (years) }\end{array}$ & $\begin{array}{c}\text { Number of } \\
\text { patients } \\
\text { investigated }\end{array}$ & EPEC & LT & ST & LT/ST \\
\cline { 4 - 6 }$<1$ & 103 & 54 & 5 & 11 & 5 \\
$1-2$ & 63 & 22 & 3 & 7 & 5 \\
$2-3$ & 23 & 8 & 1 & 3 & 0 \\
$3-4$ & 10 & 0 & 0 & 2 & 1 \\
$4-5$ & 13 & 0 & 0 & 2 & 1 \\
$>5$ & 61 & 0 & 1 & 11 & 2 \\
Total & 273 & 84 & 10 & 36 & 14 \\
\hline
\end{tabular}

Table II. Frequency and type of toxin produced by EPEC serogroups isolated from 273 patients

\begin{tabular}{|c|c|c|c|c|c|}
\hline \multirow[b]{2}{*}{$\begin{array}{c}\text { EPEC } \\
\text { serogroups }\end{array}$} & \multirow{2}{*}{$\begin{array}{l}\text { Number of } \\
\text { isolates } \\
\text { (Number } \\
\text { tested) }\end{array}$} & \multirow[b]{2}{*}{$\begin{array}{c}\text { Percentage } \\
\text { of total }\end{array}$} & \multicolumn{3}{|c|}{ Toxin type } \\
\hline & & & $\mathrm{LT}$ & ST & $\mathrm{LT}+\mathrm{ST}$ \\
\hline 020ab:K84 & $2(2)$ & $2 \cdot 38$ & 0 & 1 & 0 \\
\hline $026:$ K 60 & $5(2)$ & 5.95 & 0 & 1 & 0 \\
\hline $044:$ K 74 & $1(1)$ & $1 \cdot 19$ & 0 & 0 & 0 \\
\hline $055: \mathrm{K} 59$ & $4(4)$ & $4 \cdot 76$ & 1 & 1 & 0 \\
\hline 086a:K61 & $7(6)$ & $8 \cdot 33$ & 0 & 2 & 1 \\
\hline $0111:$ K58 & $7(7)$ & $8 \cdot 33$ & 0 & 3 & 0 \\
\hline 0119:K69 & $5(5)$ & 5.95 & 0 & 1 & 0 \\
\hline $0124:$ K 72 & $2(1)$ & $2 \cdot 38$ & 0 & 0 & 0 \\
\hline $0125:$ K 70 & $7(7)$ & $8 \cdot 33$ & 0 & 1 & 0 \\
\hline 0126:K71 & $18(18)$ & $21 \cdot 43$ & 3 & 3 & 0 \\
\hline $0127 \mathrm{a}: \mathrm{K} 63$ & $7(7)$ & $8 \cdot 33$ & 1 & 1 & 1 \\
\hline 0128:K69 & $19(17)$ & $22 \cdot 62$ & 0 & 3 & 2 \\
\hline Total & $84(77)$ & 100 & 5 & 17 & 4 \\
\hline
\end{tabular}


frequent, comprising $>65 \%$ of the enterotoxigenic strains of EPEC. Strains producing both LT and ST were the least common and only $5(6.4 \%)$ of EPEC isolates tested produced LT.

\section{Discussion}

Many reports indicate that ETEC are amongst the commonest causes of intestinal disease in different parts of the world (e.g., Nalin et al., 1975; Sack, 1975; Rowe et al., 1977). The importance of this pathogen in diarrhoeal disease in Iran has been little studied, probably because the complex biological assays needed to detect enterotoxins make them impractical in clinical laboratories and field studies. The present study demonstrates an association of all three types of ETEC with acute diarrhoea in the temperate state of Hormozgan in south Iran; $>21 \%$ of the patients studied who were between the ages of 3 months and 48 years were infected with ETEC. Strains producing ST were commonest followed by those producing both LT and ST. These results are similar to several reported from elsewhere (Sack et al., 1975; Evans et al., 1977), but differ from those obtained in Bangladesh (Ryder et al., 1976; Sack et al., 1977; Merson et al., 1979) where strains producing LT and ST predominate, and in India (Sen et al., 1984) and other parts of the world (Guerrant et al., 1975) where strains producing LT have been more frequently found. This suggests that strains producing ST and those producing both LT and ST are important causes of diarrhoea in patients of all ages in Bandar-Abbas. It must be noted that the month's interval between collection and culturing of the stool samples might

\section{REFERENCES}

Bhagwan Singh R, Kanaganayagy M, Lin E 1975 Enteropathogenic Escherichia coli in Malaysian children. South-east Asia Journal of Tropical Medicine and Public Health 6: 61-67.

De S N, Chatterjee D N 1953 An experimental study of the mechanism of action of Vibrio cholerae on the intestinal mucous membrane. Journal of Pathology and Bacteriology 66: $559-562$.

Dean A G, Ching Y C, Williams R G, Harden L B 1972 Test for Escherichia coli enterotoxin using infant mice: application in a study of diarrhea in children in Honolulu. Journal of Infectious Diseases 125 : 407-411.

Echeverria P, Blacklow N R, Sanford L B, Cukor G G 1981 Travellers' diarrhoea among American Peace Corps volunteers in rural Thailand. Journal of Infectious Diseases 143: 767-771.

Edwards P R, Ewing W H 1972 Identification of Enterobacteriaceae, 3rd edn Burgess Publishing Co., Minneapolis.

Evans D G et al. 1977 Enteropathogens associated with pediatric diarrhoea in Mexico City. Journal of Pediatrics 91 : 65-68

Evans D J, Evans D G, Du pont H L, Orskov F, Orskov I 1977 have led to an underestimation of the prevalence of such isolates.

On the other hand, EPEC strains seem to be more important in the aetiology of infantile diarrhoea only. The association of certain OK serogroups, known as EPEC, with infantile diarrhoea has been established in many parts of the world (Bhagwan et al., 1975; Gurwith et al., 1978), even though the mechanism by which they cause the disease has not been clearly defined. The possibility that these strains of human origin produce enterotoxin has been investigated (Smith and Gyles, 1970; Reis et al., 1979). Despite many investigations of different serogroups of EPEC isolated from patients with epidemic or sporadic diarrhoea, few strains have been shown to produce toxins (Gurwith et al., 1978; Levine et al., 1978). Temporary acquisition of an enterotoxin plasmid, or incomplete characterisation of EPEC serogroups, have been given as explanations for these findings (Robins-Browne, 1987). The results of the present study show the association of different EPEC serogroups with endemic diarrhoea in children under 3 years of age in Bandar-Abbas, and also that at least $33 \%$ of these strains produce LT, ST or both toxins. EPEC strains producing ST were the commonest. In view of their predominance among the ETEC isolates this is not surprising, as transfer of enterotoxin plasmids from ETEC to other bacteria by conjugation is common (Smith and Halls, 1968; Gyles et al., 1974).

Further studies now in progress may yield a better understanding of the importance of $E$. coli in diarrhoea in children and adults in other parts of Iran.

Patterns of loss of enterotoxigenicity by Escherichia coli isolated from adults with diarrhea: Suggestive evidence for an interrelationship with serotype. Infection and Immunity 17: 105-111.

Ganguly U, Sen D, Datta P, Pal S C 1980 Enterotoxigenic Escherichia coli associated with diarrhoea in children and adults at a hospital in Calcutta. Indian Journal of Medical Research 71: 498-500.

Gastrin B, Kallings L O, Marcetic A 1968 The survival time for different bacteria in various transport media. Acta Pathologica et Microbiologica Scandinavica 74 (Section B): 371-380.

Guerrant R L, Moore R A, Kirschenfeld P M, Sande M A 1975 Role of toxigenic and invasive bacteria in acute diarrhea of childhood. New England Journal of Medicine 293: 567-573.

Gurwith M, Hinde D, Gross R, Rowe B 1978 A prospective study of enteropathogenic Escherichia coli in endemic diarrheal disease. Journal of Infectious Diseases. 137: 292297.

Gyles C, So M, Falkour S 1974 The enterotoxin plasmids of Escherichia coli. Journal of Infectious Diseases 130 : 40-49.

Levine M M et al. 1978 Escherichia coli strains that cause 
diarrhoea but do not produce heat-labile or heat-stable enterotoxins and are non-invasive. Lancet 1: 1119-1122.

Merson M H et al. 1976 Travelers' diarrhea in Mexico: a prospective study of physicians and family members attending a congress. New England Journal of Medicine 294 : 1299-1305.

Merson M H, Orskov F, Orskov I, Sack R B, Huq I, Koster F T 1979 Relationship between enterotoxin production and serotype in enterotoxigenic Escherichia coli. Infection and Immunity 23 : 325-329.

Merson M H et al. 1980 Disease due to enterotoxigenic Escherichia coli in Bangladeshi adults: clinical aspects and a controlled trial of tetracycline. Journal of Infectious Diseases 141 : 702-711.

Mohadjer S, Bidanjiri A, Hafezi R, Hamidi A H 1982 The first report on the isolation of enterotoxigenic Escherichia coli as a cause of infantile diarrhoea in Iran. Iranian Journal of Public Health 11 : 77-78.

Nalin D R, McLaughlin J C, Rahaman M, Yunus M, Curlin G 1975 Enterotoxigenic Escherichia coli and idiopathic diarrhoea in Bangladesh. Lancet 2: 1116-1119.

Reis M H L, Castro A F P, Toledo M R F, Trabulsi L R 1979 Production of heat-stable enterotoxin by the $\mathrm{O} 128$ serogroup of Escherichia coli. Infection and Immunity 24: 289-290.

Robins-Browne R M 1987 Traditional enteropathogenic Escherichia coli of infantile diarrhea. Reviews of Infectious Diseases 9: $28-53$.

Rowe B, Scotland S M, Gross R J 1977 Enterotoxigenic
Escherichia coli causing infantile enteritis in Britain. Lancet 1: 90-91.

Ryder R W et al. 1976 Enterotoxigenic Escherichia coli and rotavirus-like agent in rural Bangladesh. Lancet 1 : 659-663.

Ryder R W et al. 1981 Travellers' diarrhoea in Panamanian tourists in Mexico. Journal of Infectious Diseases 144: 442448.

Sack D A, Merson M H, Wells J G, Sack R B, Morris G K 1975 Diarrhoea associated with heat-stable enterotoxin producing strains of Escherichia coli. Lancet 2: 239-241.

Sack D A, McLaughlin J C, Sack R B, Orskov F, Orskov I 1977 Enterotoxigenic Escherichia coli isolated from patients at a hospital in Dacca. Journal of Infectious Diseases 135: 275280.

Sack R B 1975 Human diarrheal disease caused by enterotoxigenic Escherichia coli. Annual Reviews of Microbiology 29: 333-353.

Sen D et al. 1984 Studies on Escherichia coli as a cause of acute diarrhoea in Calcutta. Journal of Medical Microbiology 17: 53-58.

Sereny B 1955 Experimental shigella Keratoconjunctivitis. Acta Microbiologica Hungarica 2: 193-196.

Smith H W, Halls S 1968 The transmissible nature of the genetic factor in Escherichia coli that controls enterotoxin production. Journal of General Microbiology 52: 319-334.

Smith H W, Gyles C L 1970 The effect of cell-free fluid prepared from cultures of human and animal enteropathogenic of Escherichia coli on ligated intestinal segments of rabbits and pigs. Journal of Medical Microbiology 3: 403-409. 